\title{
Musical Activity in The Music Learning Process Through Children Songs in Primary School Level
}

\section{${ }^{\circledR}$ Syahrul Syah Sinaga ${ }^{1}$, Tjetjep Rohendi Rohidi ${ }^{1}$, Soesanto ${ }^{1}$, Victor Ganap ${ }^{2}$}

\author{
${ }^{1}$ Postgraduate Program, Unversitas Negeri Semarang, Indonesia \\ ${ }^{2}$ Postgraduate Program, Institut Seni Indonesia Yogyakarta, Indonesia
}

Received: December 29, 2017. Revised: April 23, 2018. Accepted: June 10, 2018

\begin{abstract}
This study aims to analyze and describe the musical activity in the process of learning music through children songs in primary school. A qualitative approach in this research is made by focusing on the field research method. Data were collected by observation techniques, interviews, and documentation studies. Data analysis was done by following certain stages respectively, i.e. data collection, data reduction, data display, conclusion drawing, and verification. The results showed that musical activities implemented in three primary schools consist of (1) listening to music; (2) singing; (3) playing musical instruments; (4) moving to follow the music; and (5) reading music. However, forms, types, and variations of the musical activities taking place in these schools are different, depending on the schools' policy, schools' abilities, and music teachers' abilities in teaching the music subject.
\end{abstract}

Keywords: Children Song; Musical Activity; Music Learning

How to Cite: Sinaga, S. S., Rohidi, T. R., Soesanto, \& Ganap, V. (2018). Musical Activity in The Music Learning Process Through Children Songs in Primary School Level. Harmonia: Journal of Arts Research And Education, 18(1), 45-51. doi:http:/ / dx.doi.org/10.15294/harmonia.v18i1.12508

\section{INTRODUCTION}

Syaodih (1998) in Mulyasa (2008) suggests that teachers play an important role in planning and implementing the curriculum. Besides the role of teacher as a planner, implementer, and curriculum developer for his class, the teacher also has the task in evaluating each curriculum refinement process. In the context of art education in primary school level, the role is carried out by the subject teacher of Cultural Arts and Craft Arts (SBK) and Art Culture and Craft Arts (SBdP).

In the 2013 Curriculum for primary school, there are three types of song that should be taught in the teaching and lear- ning process of music in Cultural Arts and Craft Arts subject, i.e. national songs, folk song, and children song. However, lack of understanding of teaching materials, such as rhythmic and measure (bar), reading and writing the musical notation, as well as the skills of developing and creating teaching materials are the main obstacles among teachers. As a result, students' experiences of musical activities are varying depending on the teacher's creativity as a planner, implementer, and curriculum developer.

The problem of differences in the execution of a musical activity that occurs in every school, principal policy, and teacher creativity in determining the teaching ma-

\footnotetext{
${ }^{\square}$ Corresponding author: Jl. Kelud Utara 3 Semarang, Indonesia

E-mail: sinagaunnes@gmail.com
} 
terials are the reasons why this research is needed. Concerned with creativity, Csikszentmihalyi (1999) says that creativity will arise when a person makes a change in the realm that will be transmitted by time. Some individuals can even make a difference because of their personal qualities or have a lucky position in their realm. In the realm of art education, they are art critics, lecturers or art teachers, school leaders, artists and art galleries. The role of each individual has an enormous influence especially in the development of music that can be enjoyed by the children.

According to the implication theory of the perspective system by Mihaly Csikszentmihalyi, a novelty of creativity can be generated through the process of interaction between the individual with his personal background, his cultural domain, and the community in the field (Sternberg, 1999). In addition to that, Csikszentmihalyi also reveals that creativity is an ability to create appropriate novelty works. The creativity itself arises through a symbolic system of how the social system responds to the new idea. If the novelty idea passes the selection and is able to provide benefits, then the idea can be manifested.

Rohidi (2016) in his book entitled Art Education: Issues and Paradigms says that art education includes the art of music in a broader context aimed at ensuring every child and adult to get the rights of education and the opportunity to engage in development and participation in the field of culture and artistic. This is a fundamental argument for raising the importance of art education as a major component of educational programs. This is relevant to Read $(1970$, p.1) in his book, "Education Through Art," that art should be the basis of education.

Department of National Education (Yustisia, et al., 2007) suggests that art education is conceptually multilingual, multidimensional, multicultural, and multi intelligence. Multilingual means the art of developing the ability of learners in expressing themselves creatively with various languages, such as: form langu- age, word language, voices, language of motion, role language, and the possibility of combination between the two. Multidimensional contains the understanding that art is a medium for the development of various competencies of learners, including knowledge, understanding, analysis, evaluation, appreciation, expression, and creation by harmoniously integrating elements of aesthetics, logic, and ethics. Culture implies that art as a medium is able to cultivate awareness and ability of learners in appreciating the diverse culture inside the country and among other countries. As for multi intelligence, the role of art in education is to form a harmonious person in accordance with the psychological development of learners in intrapersonal, interpersonal, visual-spatial, verbal linguistic, musical, mathematical, physical-kinesthetic, and so on.

In the context of music subject, Gough and Millar (2015) revealed that giving musical activity is important for children. This activity needs to be done because it allows children to explore feelings and express those feelings using several ways that will support them. In addition, activities also provide opportunities that explain the musical experience of children in classrooms, groups and as an individual.

Moreover, research from Temmerman (1995) showed that the responds of students to the musical experience that was given to four schools from four different regions were the same; although each region has different socio-economic, population, facilities and infrastructure in the learning process. In addition, his research also reveals the stages of activities performed in musical activities include singing, playing games, listening to music, playing musical instrument, and moving by following music that integrates with curriculum or other planning.

Related to the needs of children in expressing himself through the song, Sinaga (Radar Semarang, Friday, 18 March 2016) stated as follows:

"Nowadays a lot of children's television shows singing adult songs. It can 
affect the child's own psychological condition."

Referring to the statement, it shows that the role of media in serving children's songs both in the event of talent competition show and entertainment programs at this time is still less. Such condition can negatively affect the quality of musical experiences experienced by learners. Therefore, Barnes (in Philpott, 2001) says that teacher training institutions have great challenges in assisting classroom teachers, especially those who teach SBK and SBdP to think creatively in developing teaching materials to give a positive impact for the learning achievement.

Related to that, this study focuses on teacher's efforts in designing various musical activities in music learning through children's songs in primary school.

\section{METHOD}

This research was conducted by using qualitative approach focused on field research method. This approach was chosen because it is relevant to the understanding of musical and teacher creativity in music learning through children songs.

Referring to the principle of qualitative research, researchers act as a key instrument. Therefore, researchers visited the field directly, adjusting to local time and space to obtain data (see Milles \& Huberman, 1992). In addition, researchers attempt to build rapport with the subject and other informants in order to obtain comprehensive information.

The research was conducted in three primary schools, namely SD Negeri 01 Ungaran, SD Mardi Rahayu 01 Ungaran, and SD Mardi Rahayu 02 Ungaran. Research subjects include: (1) classroom teachers and music teachers in three schools that teach SBK and SBdP subjects in the field of music; (2) the principal who participates in supporting the realization of subjects in school life; (3) managers of foundations or committees as policy supporters in the learning process of music in schools.

Data collections techniques used in this study were observation, interviews, and documentation studies. Therefore, various data related to musical activity in the learning process of music at primary school level can be obtained completely. Data analysis is done in four stages: data collection, data reduction, data presentation, as well as conclusion and verification.

\section{RESULTS AND DISCUSSION}

\section{Musical activity in musical lerning pro- cess}

In general, music teachers in primary schools are classroom teachers who are formally prepared to become teachers in various fields of study such as Natural Sciences (IPA), Social Sciences (IPS), Mathematics, Language, and Art. As a result, while teaching music, some teachers in many schools are experiencing difficulties. Based on observations in the field, the teachers who have competence in the field of music are reflected from their mastery of the basic elements of music in musical activities such as singing and/or playing a musical instrument. These competencies are generally not derived from the results of learning in formal education institutions, but because by chance they are born from the family who pursue the field of art (artists). In addition, some other teachers had experience in music since they were either a band player at school or an autodidact who learned music by themselves.

Basically, musical activities in music learning consist of listening to music, responding to music with rhythmical motion (responding), singing (singing), reading music notation (reading) and recording music (recording), playing instruments (playing), as well as analyzing and appreciating (Jamalus, 1988; Safrina, 1999; UNESCO, 2002; Temmerman, 1995; and Utomo, 2017). Therefore, in reference to the theory of musical activity, this research will explain the varieties of musical activity that take place in the process of learning music through children songs at the primary school level in Semarang regency. Musical activity is an important 
component in music learning to provide a musical experience to the students. However, because of the various school conditions and competence of existing teachers, the capacity and form of musical activity that is held in each school are different. The data obtained from the three primary schools studied showed that listening to music, singing, playing music, reading music notation, and moving following the music are some forms of activities that have taken place in music learning. However, in the context of the use of music as a medium of learning, teachers have used the composition of various musical compositions, musical instruments, and electronic equipment to teach (see Utomo, 2017). The practice of all these five musical activities can be described as follows.

\section{Listening music activites}

The observation result from SD Negeri 01 Ungaran showed that the musical activity took place mainly when the teacher gave an example of a song in music learning. For example, when the researcher observed music learning in second and fifth grade. The process of giving musical experience through songs in both classes is done by the teacher through the audio media and singing the song directly.

A second grade teacher once said that, teaching the folk song material "Sio Tantina" and "Padang Wulan" in accordance with the national curriculum 2013 is done by playing the two recordings of the song. As one of the strategies, the recording is collected by downloading the song through the internet. However, in the sixth grade, the three stanzas Indonesian anthem are taught by asking the students to listen to the songs sung by the teacher. However, since the students have mastered the melody of the taught song, the listening activity is focused on the three stanzas lyrics of the song. Furthermore, the learning activities are done by the students by imitating the pronunciation of all the lyrics of the songs according to the existing melody sentence. Through these two musical activities, comprehensively, the students obtain a mea- ningful musical experience with regards to song lyrics, tempo, high pitch (tone), and tone value (duration).

Related to the activity of listening to music, according to the principal of SDN Ungaran 01, basically the students have gained experience from the family environment, electronic media, and through their interaction with peers. Although, not every song listened by the students are match with the characteristics, development, and needs of students.

On the contrary, unlike the students of SD Negeri 01 Ungaran, listening to music among students of SD Mardi Rahayu 01 and 02 Ungaran is more diverse. As an educational institution incorporated in the Catholic Foundation, the students have been intensively gained musical experience while attending church services with some additions to other experiences gained from the family environment, electronic media, and interaction with peers.

In both schools, the listening activity of music in various forms has been adequately implemented. Through extracurricular activities, this activity is obtained through the activities of choir, drumband, and karawitan (Javanese traditional music). In fact, according to the principal of SD Mardi Rahayu, the teachers or school attendants have the task of playing music like national songs, educational themed songs, and Mars of the school by using tape recorders equipped with sound system devices every morning. The playback of these songs is an effort to build the character education that must be done in every primary school in Semarang regency. Even in these two schools, the church songs also played especially at the time before the church mass. In addition to this, playing the Javanese song or gendhing (klonengan) is an effort to introduce traditional art to the students.

\section{Singing activities}

Singing is a tool for children to express their thoughts and feelings through tones and words. Therefore, singing is one part of musical activity that is important and dominant to be implemented in the 
school. Singing activities are always be loved by students. Through this expressional activity, the students are able to gain satisfaction that is meaningful for themselves as an effort to develop their artistic and aesthetic ability.

Singing activities in the three primary schools studied were conducted in accordance with the policies of each school. Some of the schools routinely do the activity at the time: (1) before the bell rings as a sign of learning begins; (2) when marching with footsteps in place before entering the classroom; (3) when learning cultural art and crafts; (4) before the finish school bell; and (5) when flag ceremonial activities on Mondays or national big day flag ceremonies.

In SD Negeri 01 Ungaran, as told by the principal, the routine of learner activities that include singing activities, should be done by first up to sixth grade. Every day before all the students enter the class, they have to gather in front of each class, then marching in front of the door led by the chairman of the class. Singing activity is done while walking on the spot with the accompaniment of students' applause along with the rhythm of the song. For example, at the time when the researcher conducted the observation, the song that was sung by the third grade students was the song of Indonesian Character Student. Meanwhile, the song which was sung by the fourth grade student was Mars of SDN Ungaran 01 song entitled "Jayalah SD Ku" by Y Subagyo.

Singing activities conducted at SD Mardi Rahayu is done in different ways. According to the principal of SD Mardi Rahayu, this activity is done regularly and together in all classes at 7 a.m. In this school, all class teachers and administrative staff gather in the office and then do prayer activities together. While at the same time, all the students in each class are also doing prayer activities together continued by singing Mars Mardi Rahayu song created by Y. Subagyo which the notation of the song has been written on the cover of all students' notebooks. That mars song is sung simultaneously with one voice (unisono) led by the class president. After classroom teachers are present in the classroom, the activity then proceeds with the process of teaching and learning activities in accordance with the schedule of school subjects in each class.

\section{Playing music activities}

The activity of playing music in SD Negeri 01 Ungaran is done both as intracurricular and extracurricular learning activities. In the intracurricular instruction, the teacher teaches the material on how to play a pianica instrument or a soprano recorder. While in extracurricular activities, this activity takes place in the marching band activity.

The learning activities of playing musical instruments in SD Negeri 01 Ungaran are carried out in groups. For example in the fourth grade, to facilitate the implementation of learning, teachers divide the students into two groups. One group of students plays pianica music instruments and one group of other students played a soprano recorder instrument.

The learning of playing musical instruments at SD Mardi Rahayu 01 and Mardi Rahayu 02 are taught by art teacher from the foundation. This policy is taken because the burdens of existing class teachers that are considered heavy and not all teachers are competent in teaching music. Based on the results of research conducted in class 4-A, one of the song material used in learning a pianica musical instrument is the traditional song from Central Java "Gundul-Gundul Pacul". Before the students learn the notation of the song that will be played, the teacher first teaches about the technique of puffing and fingering of natural scales (C Major).

\section{Moving following the music activities}

Implementation of activities to move following music in SD Negeri 01 Ungaran can be found every morning before the students go to class and begin the learning activities. All students ranging from grade 1 to 6 should do march accompanied 
by a classroom teacher before entering the class. The activity is followed by students sang the character education song while performing the movement; following the songs that the students had memorized. The songs sung by the students in each class are not the same, some of them singing Mars of SD Negeri 01 Ungaran, Mars PPK Siswa Berkarakter Indonesia, Mars Pendidikan Keluarga, and ABITA.

Some of the activities in moving body to follow the music in SD Mardi Rahayu include the conducting material songs that took place in the $3 \mathrm{rd}$ and 4 th grade. The song used as a learning medium to is the song of Indonesia Raya with Time Signature $4 / 4$. The learning process is done by the teacher, starting with giving examples of hand movement pattern $4 / 4$ while singing Indonesia Raya song. Then, students practice it together with teacher guidance. Hand movement is as follows.

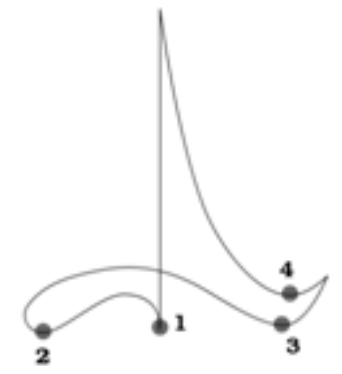

Figure 1. 3/4 Graphic Hand Measure Movement 4/ 4 (Source: Sinaga, October 2017)

\section{Reading music notation activity}

Reading musical notation is a musical activity that requires the basic skills of music and musical theory. In the form of activities, this activity can be done by using vocals through singing activities or using musical instruments by playing music activities.

Implementation of reading music notation activity that took place in SD Negeri 01 Ungaran has been implemented in all grade levels. However, when teaching grade 1 to grade 3 , this activity is only done during singing activities. In practice, at the time of singing activities teachers always write the notation of the song in the form of notes on the board. So indirectly, when the singing activities are done, students also begin to be introduced with tone symbols, tone (picth), tone value, and song tempo.

In contrast to those taking place in grades 1 to 3 , in grades 4 and 5 students have been taught in more depth about ways of reading music notation especially number notation. In practice, this activity is implemented through the activities of singing and playing musical instruments. At the time of playing a musical instrument, other than students applying their knowledge of tone symbols, tone values, and tempo, they also learn about the position of the tone, how to blow pianica and play recording instruments played, and also fingering techniques.

In SD Mardi Rahayu 01 and SD Mardi Rahayu 02 Ungaran, learning activities that involve reading music notation activity are begun from third grade. This activity is structured in the order of materials, the introduction of the number notation and music symbol notation, how to write notation, and the procedure of transposing the number notation into the music symbol notation or vice versa. After that, it is continued by making the application through the activities of singing and playing musical instruments. The practice of reading music notation through the playing of the musical instrument is done by using pianica. At the time of learning in grade 4 , the activity of reading music notation using a musical instrument is done with numbered notation. However, when students learning music in the $5^{\text {th }}$ grade, the application of the use of music symbol notation has started to be taught to the students.

Based on Tarwiyah (2003), in practicing the soprano recorder music instrument, it will be more effective if it is done through the use of music symbol instrument. Therefore, when the teacher has the ability to teach the music symbol notation, teaching the music symbol notation can be applied from primary level in a simple way. 


\section{CONCLUSION}

Based on the research results, it is shown that the musical activities in SDN 01 Ungaran, SD Mardi Rahayu 01, and SD Mardi Rahayu 02 Ungaran consist of: (1) listening music activities; (2) singing activities; (3) playing music activities; (4) moving following the music activities; and (5) reading music notation activities. Those five musical activities are experienced by students outside the learning process, intracurricular, and extracurricular.

The intensity and quality of musical activities given to the students in primary schools that were researched are different. Those differences are caused by the different school regulations, teachers education, as well as teachers' musical ability and experiences. Different musical activities can be seen from the variety of musical activities which were done outside of the the planned learning activity, intracurricular, and extracurricular acivities.

\section{REFERENCES}

Csikszentmihaly, M. (1996). The Creative Personality. Psychology Today, 29(4), 36-40.

Gough, M. Peter Millar. (2012) Curriculum Support Teacher for Music. London:Neelbg

Jamalus. (1988). Panduan Pengajaran Buku Pengajaran Musik Melalui Pengalaman Musik. Jakarta: Proyek Pengembangan Lembaga Pendidikan.

Miles, H B. \& Huberman A M. (1992). Analisis Data Kualitatif (terj. Tjetjep Rohendi Rohidi). Jakarta: UI Press.

Mulyasa. (2008). Menjadi Guru Professional, Menciptakan Pembelajaran Kreatif dan Menyenangkan. Bandung:
Remaja Rosdakarya.

Philpott, C. \& Charles Plummeridge (Eds.) (2001) Issues in Music Teaching. London: Routledge Falmer.

Read, Herbert. (1970). Education through Art. Chicago: University of Illinois Press.

Rohidi, T.R., (2016). Pendidikan Seni: Isu dan Paradigma. Semarang: Cipta Prima Nusantara Semarang.

Safrina, R. (1999). Pendidikan Seni Musik. Jakarta: Depdikbud.

Sinaga, Syahrul S. (2016, Maret 18). Prihatin Lagu Anak Minim. Radar Semarang: 11.

Sternberg, R. J. (Eds.). (1999). Handbook of Creativity. Cambridge: Cambridge University Press.

Tarwiyah, T. (2003). Perbedaan Efektifitas antara Penggunaan Notasi Balok dengan Notasi Angka dalam Meningkatkan Ketrampilan Memainkan Rekorder Sopran Pada Mahasiswa Pendidikan Anak Usia Dini (PAUD) Iniversitas Negeri Jakarta. Harmonia: Journal of Art Research and Education, 10(1)

Temmerman, Nita. (1995). Children's Perceived Best and Worst Classroom Music Experience. Proceeding. Dipresentasikan pada Seminar ke-10 "Australian Society for Music Education".

Tim Pustaka Yustisia. (2007). Panduan Lengkap KTSP. Yogyakarta: Tim Pustaka Yustisia.

UNESCO, (2006). "Road Map for Arts Education". The World Conference on Art Education Building Creative Capacities for the 21 $1^{\text {st }}$ Century. Lisbon, 6-9 March.

Utomo, Udi. (2017). (2016). Musik Pendidikan. Semarang: Jurusan Sendratasik FBS UNNES 